\title{
Characterization and Classification of Soils of Madahalli Micro-watershed of Karnataka
}

\author{
R. Vasundhara*, M. Chandrakala, S. Dharumarajan, B. Kalaiselvi, \\ Rajendra Hegde and S.K. Singh \\ ICAR-National Bureau of Soil Survey and Land Use Planning, Regional Centre, \\ Bengaluru-560024, Karnataka, India
}

\begin{abstract}
Detailed soil survey was carried out to characterize and classify the soils of Madahalli watershed, Chamrajanagar district, Karnataka using cadastral map overlaid on Cartosat-1(ortho corrected) image as a base. Three landform units were identified based on elevation and slope i.e. gently sloping lands (3-5\%), very gently sloping lands (1-3\%) and nearly level lands (0-1\%) and mapped into 6 soil series and 30 phases of soil series. These soils were classified as Alfisols (Typic Rhodustalfs, Rhodic Paleustalfs) and Inceptisols (Typic Haplustepts). Alfisols are slightly deep to deep, dark reddish brown to strong brown in hue 2.5 YR $3 / 4$ to 2.5 YR 4/6, sandy loam to sandy clay in texture with $>35$ per cent gravel. Inceptisols are very deep, yellowish brown to dark brown with hue 10YR 4/6 to $10 \mathrm{YR} 3 / 3$, sandy clay loam to clay in texture. These soils are moderately acidic to moderately alkaline ( $\mathrm{pH} 5.26$ to 8.17). The organic carbon content varied from low to high $(0.21$ to $1.16 \%)$ and CEC of the soils ranged from 4.1 to $19.9 \mathrm{cmol}(\mathrm{p}+) \mathrm{kg}^{-1}$.
\end{abstract}

Keywords: Soil survey and mapping, remote sensing, Alfisols, Inceptisols, Taxonomy

\section{Introduction}

Land and water are the most vital natural resources of the country and these are under tremendous stress due to ever increasing biotic pressure. Characterization of soils is fundamental to all soil studies, as it is an important tool for soil classification, which is done based on soil properties. It also provides information for understanding of the physical, chemical and mineralogical properties of the soils and an insight into the potentials and limitations of the soils for management. The soil and land resource inventories made so far in Karnataka had limited utility because the surveys were of different types, scales and intensities at different times with specific objectives. Hence, there is need to generate detailed site-specific farm level database on different land resources for all the

*Corresponding author: (Email: vasundharagowda@gmail.com) village/watersheds in a time bound manner that would help to protect the valuable land resources and also to stabilize the farm production and characterization of Madahalli micro-watershed of Gundlupet taluk, Chamrajnagar district is one of the case study in this direction.

\section{Materials and Methods}

Madahalli micro-watershed is located in Kodasogegrama panchayath, Terakanambi Hobli, Gundlupet taluk of Chamarajnagar district (Fig.1). The micro-watershed with total area of 698 hectares (76 $46^{\prime} 15.16^{\prime \prime}$ and $76^{\circ} 48^{\prime} 15^{\prime \prime} \mathrm{N}$ latitude) and $11^{\circ} 43^{\prime}$ $05.91^{\prime \prime}$ and $11^{\circ} 44^{\prime} 43.13^{\prime \prime}$ E longitude) is located at about $30 \mathrm{kms}$ southeast from Gundlupet. The watershed covers Karkla Madahalli (298 ha), Thodipura (172 ha), Vaddagere (49 ha) Alwadi (178 ha) and Kodasoge (4 ha) villages. 


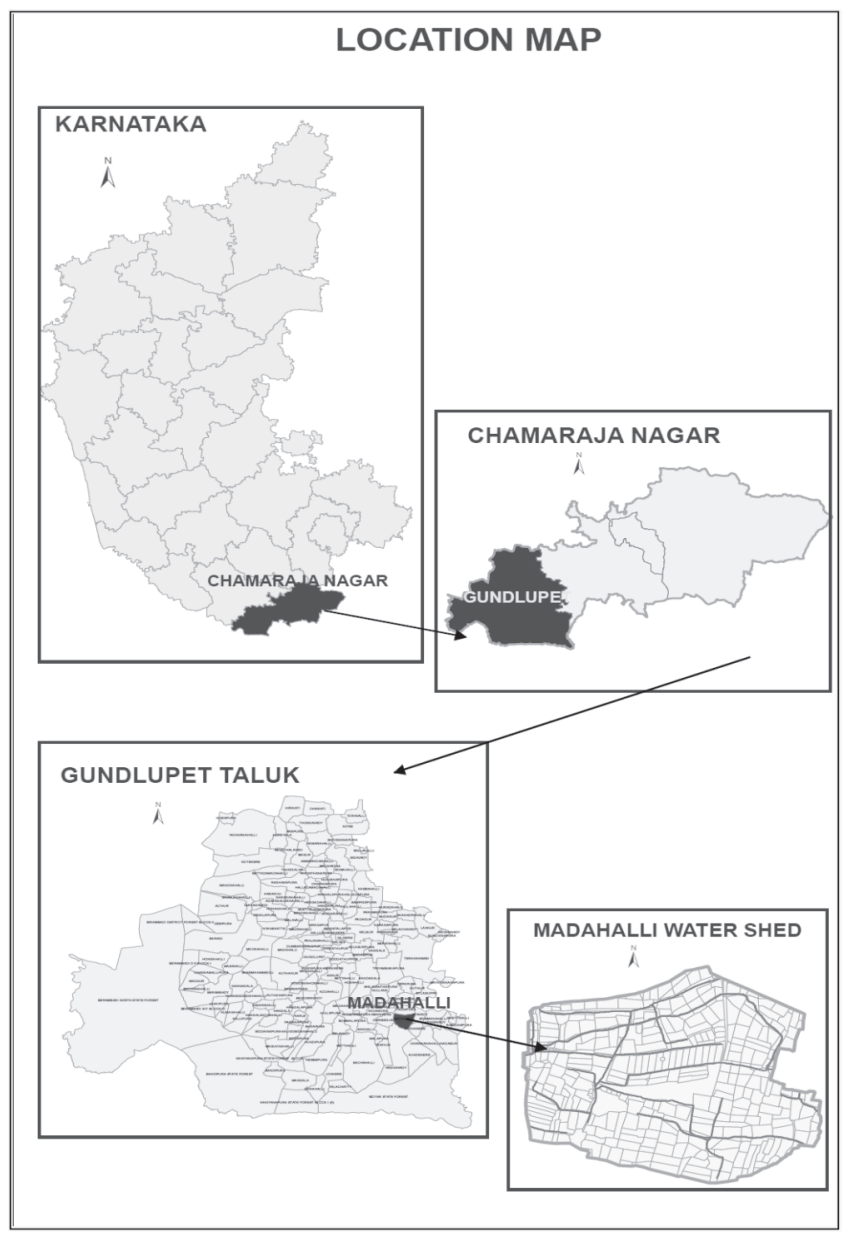

Fig. 1. Location map of study area

Granite and granite-gneiss are the major rock types in the watershed. The elevation of the area ranges from 868 to $919 \mathrm{~m}$ above mean sea level (MSL). The area is very gently sloping to gently sloping uplands with slope ranging from 1 per cent to 5 per cent. The area can be broadly divided into three landform units based on elevation and slope and they are gently sloping lands (3-5\%), very gently sloping lands (1-3\%) and nearly level lands $(0-1 \%)$. Very gently to gently sloping land cover about 67 per cent and nearly level land occupies 30 per cent of the watershed. The climate of the area is semi-arid transition characterized by hot and dry summer with mild winter. The annual precipitation is $734.5 \mathrm{~mm}$ and the annual temperature is $23.7^{\circ} \mathrm{C}$. Length of growing period (LGP) ranges from 90 to 120 days. Soil moisture regime is ustic and soil temperature regime is isohyperthermic. Pongamia (Pongamia pinnata), Neem (Azadirachta indica), Lantana (Lantana camera), Tamarind (Tamarindus indica), Soapnut tree (Acacia concinna), Pipal (Ficas religiosa), are the natural vegitation. The major crops grown are ragi (Eleusine coracana), groundnut (Arachis hypogaea), pigeonpea (Cajanus cajan), castor (Ricinus communis), mango (Mangifera indica) etc.

Detailed survey of the watershed was carried out by using Cartosat-1 image in conjunction with cadastral map as a base. A total of six pedons were exposed and studied from each landform for describing morphological characteristics (Soil Survey Staff 2010). Horizon-wise soil samples were collected, processed and analysed for particle size distribution, $\mathrm{pH}, \mathrm{EC}$, organic carbon and cation exchange capacity following the procedure outlined by Black (1965).

\section{Results and Discussion \\ Soil morphology}

The pedons were slightly deep to very deep. The colour is in the hue of 7.5YR, 5YR and 2.5YR with value 3 to 4 and chroma 4 and 6. In general, pedons had dark brown, dark reddish brown surface and dark reddish brown to reddish brown sub-surface horizons except pedon 6 . These pedons have thin patchy cutans in sub-surface soils except $\mathrm{P}_{6}$. Structure of the soils are weak fine to medium weak subangular blocky in surface to moderate medium subangular blocky in sub-surface soils. (Table 1)

\section{Physical characteristics}

The particle size data (Table 2) indicated that the clay content varied from 13.4 to 41.4 per cent and gradually increased in the sub-surface layers and then decreased. Meena et al. (2014) also recorded similar trend of clay illuviation in lowland soils in Mandya District of Karnataka. Silt content varied from 2.7 to 19.8 per cent and it was irregularly distributed in all the pedons. Sand content varied from 44.0 to 83.2 per cent being high in surface layers. Coarse fragments varied from 5 to 70 per cent with irregular distribution with depth. 


\section{Chemical characteristics}

The $\mathrm{pH}$ of the soils varied from 5.26 to 8.20 (moderately acid to moderately alkaline). In some pedons, $\mathrm{pH}$ increased with depth which could be due to the leaching of exchangeable bases from the surface horizon. Electrical conductivity varied from 0.027 to $0.129 \mathrm{mSm}^{-1}$ indicating that the soils are non-saline. Organic carbon content varied from low to high ( 0.21 to 1.23 per cent) and in few pedons it increased with depth and then decreased in lower layers. Cation exchange capacity of the soils varied from 4.1 to $19.9 \mathrm{cmol}$ $(\mathrm{p}+) \mathrm{kg}^{-1}$ and in general increased with depth. (Table 2) Among exchangeable bases, exchangeable $\mathrm{Ca}^{2+}$ was higher (1.88 to $\left.10.05 \mathrm{cmol}(\mathrm{p}+) \mathrm{kg}^{-1}\right)$ and the exchangeable cations followed in the order as $\mathrm{Ca}>\mathrm{Mg}>\mathrm{Na}>\mathrm{K}$. Exchangeable calcium had positive correlation with clay and $\mathrm{pH}$. Base saturation of the soils is more than 35 per cent and pedon 6 had base saturation $\approx 100$ per cent. The exchangeable $\mathrm{Ca}^{2+}$ and $\mathrm{Mg}^{2+}$ contributed for higher base saturation in these soils. Similar results were also reported by Srinivasan et al. (2013) and Meenaetal. (2014).

Table 1. Morphological features of typical pedons of Madahalli micro-watershed

\begin{tabular}{|c|c|c|c|c|c|c|c|}
\hline Pedons & Horizon & $\begin{array}{l}\text { Depth } \\
\text { cm }\end{array}$ & $\begin{array}{l}\text { Colour } \\
\text { (moist) }\end{array}$ & Structure & $\begin{array}{c}\text { Consis- } \\
\text { tence }\end{array}$ & $\begin{array}{l}\text { Coarse } \\
\text { fragments }\end{array}$ & $\begin{array}{c}\text { Special } \\
\text { features }\end{array}$ \\
\hline \multirow[t]{5}{*}{ Pedon 1} & Ap & $0-18$ & $7.5 \mathrm{YR} 4 / 4$ & $\mathrm{~m} 1 \mathrm{sbk}$ & fr, so, po & 10 & - \\
\hline & $\mathrm{AB}$ & $18-29$ & $2.5 \mathrm{YR} 4 / 4$ & $\mathrm{~m} 2 \mathrm{sbk}$ & fr, ss, sp & 5 & $\mathrm{~T} \operatorname{tn} \mathrm{p}$ \\
\hline & Bt1 & $29-48$ & $2.5 \mathrm{YR} 3 / 4$ & $\mathrm{~m} 2 \mathrm{sbk}$ & fr, ss, sp & 60 & $\mathrm{~T}$ tn $\mathrm{p}$ \\
\hline & $\mathrm{Bt} 2$ & $48-69$ & $2.5 \mathrm{YR} 3 / 6$ & $\mathrm{~m} 1 \mathrm{sbk}$ & $\mathrm{fr}, \mathrm{ss}, \mathrm{sp}$ & 25 & $\mathrm{~T} \operatorname{tn} \mathrm{p}$ \\
\hline & $\mathrm{Cr}$ & $69+$ & \multicolumn{5}{|c|}{ Weathered granite gneiss } \\
\hline \multirow[t]{5}{*}{ Pedon 2} & Ap & $0-22$ & $5 Y R 3 / 4$ & $\mathrm{~m} 1 \mathrm{sbk}$ & $\mathrm{fr}, \mathrm{ss}, \mathrm{sp}$ & - & - \\
\hline & Bt1 & $22-46$ & $2.5 \mathrm{YR} 3 / 6$ & $\mathrm{~m} 2 \mathrm{sbk}$ & $\mathrm{fr}, \mathrm{ms}, \mathrm{mp}$ & 50 & $\mathrm{~T}$ tn $\mathrm{p}$ \\
\hline & $\mathrm{Bt} 2$ & $46-74$ & $2.5 \mathrm{YR} 3 / 6$ & $\mathrm{~m} 2 \mathrm{sbk}$ & $\mathrm{fr}, \mathrm{ms}, \mathrm{mp}$ & 45 & $\mathrm{~T}$ tn $\mathrm{p}$ \\
\hline & $\mathrm{Bt} 3$ & $74-96$ & $2.5 \mathrm{YR} 3 / 4$ & $\mathrm{~m} 1 \mathrm{sbk}$ & $\mathrm{fr}, \mathrm{ss}, \mathrm{sp}$ & 20 & $\mathrm{~T}$ tn $\mathrm{p}$ \\
\hline & $\mathrm{Cr}$ & $96+$ & \multicolumn{5}{|c|}{ Weathered granite gneiss } \\
\hline \multirow[t]{4}{*}{ Pedon 3} & Ap & $0-13$ & 7.5YR 3/4 & flsbk & $\mathrm{fr}, \mathrm{s} 0, \mathrm{p} 0$ & 5 & \\
\hline & Bt1 & $13-41$ & $2.5 \mathrm{YR} 3 / 4$ & $\mathrm{~m} 2 \mathrm{sbk}$ & $\mathrm{fr}, \mathrm{ms}, \mathrm{mp}$ & 10 & $\mathrm{~T}$ tn $\mathrm{p}$ \\
\hline & $\mathrm{Bt} 2$ & $41-83$ & $2.5 \mathrm{YR} 3 / 4$ & $\mathrm{~m} 2 \mathrm{sbk}$ & $\mathrm{fr}, \mathrm{ms}, \mathrm{mp}$ & 60 & $\mathrm{~T}$ tn $\mathrm{p}$ \\
\hline & $\mathrm{Cr}$ & $83+$ & \multicolumn{5}{|c|}{ Weathered granite gneiss } \\
\hline \multirow[t]{5}{*}{ Pedon 4} & Ap & $0-13$ & $7.5 \mathrm{YR} 4 / 4$ & flsbk & 1, so, po & 10 & - \\
\hline & Bt1 & $13-36$ & $2.5 \mathrm{YR} 3 / 6$ & $\mathrm{~m} 1 \mathrm{sbk}$ & $\mathrm{f}, \mathrm{ms}, \mathrm{mp}$ & 70 & $\mathrm{~T}$ tn $\mathrm{p}$ \\
\hline & $\mathrm{Bt} 2$ & $36-61$ & $2.5 \mathrm{YR} 3 / 6$ & $\mathrm{~m} 1 \mathrm{sbk}$ & $\mathrm{f}, \mathrm{ms}, \mathrm{mp}$ & 65 & $\mathrm{~T} \operatorname{tn} \mathrm{p}$ \\
\hline & Bt3 & $61-83$ & $2.5 \mathrm{YR} 3 / 4$ & $\mathrm{~m} 1 \mathrm{sbk}$ & $f, m s, m p$ & 60 & $\mathrm{~T}$ tn $\mathrm{p}$ \\
\hline & $\mathrm{Cr}$ & $83+$ & \multicolumn{5}{|c|}{ Weathered granite gneiss } \\
\hline \multirow[t]{6}{*}{ Pedon 5} & Ap & $0-20$ & $5 Y R 3 / 4$ & $\mathrm{~m} 1 \mathrm{sbk}$ & $\mathrm{fr}, \mathrm{ss}, \mathrm{sp}$ & - & - \\
\hline & Bt1 & $20-38$ & $5 Y R 4 / 4$ & $\mathrm{~m} 1 \mathrm{sbk}$ & $\mathrm{fr}, \mathrm{ss}, \mathrm{sp}$ & - & $\mathrm{T}$ tn $\mathrm{p}$ \\
\hline & Bt2 & $38-69$ & $2.5 \mathrm{YR} 3 / 6$ & $\mathrm{~m} 2 \mathrm{sbk}$ & $\mathrm{fr}, \mathrm{ms}, \mathrm{mp}$ & - & $\mathrm{T}$ tn $\mathrm{p}$ \\
\hline & $\mathrm{Bt} 3$ & $69-98$ & $2.5 \mathrm{YR} 3 / 4$ & $\mathrm{~m} 2 \mathrm{sbk}$ & $\mathrm{fr}, \mathrm{ms}, \mathrm{mp}$ & 40 & $\mathrm{~T} \operatorname{tn} \mathrm{p}$ \\
\hline & $\mathrm{Bt} 3$ & $98-134$ & $2.5 \mathrm{YR} 3 / 4$ & mlsbk & $\mathrm{fr}, \mathrm{s}, \mathrm{p}$ & 50 & $\mathrm{~T}$ tn $\mathrm{p}$ \\
\hline & $\mathrm{Cr}$ & $134-188$ & \multicolumn{5}{|c|}{ Weathered granite gneiss } \\
\hline \multirow[t]{6}{*}{ Pedon 6} & Ap & $0-26$ & 10YR 4/4 & flsbk & $1, \mathrm{ss}, \mathrm{sp}$ & - & \\
\hline & $2 \mathrm{~A} 21$ & $26-51$ & 10YR 4/6 & flsbk & 1, so, po & - & \\
\hline & $3 \mathrm{Bw} 1$ & $51-72$ & 10YR 4/6 & m1sbk & 1, so, po & - & Pressure faces \\
\hline & $4 \mathrm{Bw} 2$ & $72-104$ & $10 Y R 4 / 4$ & $\mathrm{~m} 2 \mathrm{sbk}$ & h, vs, vp & - & Pressure faces \\
\hline & $5 \mathrm{Bw} 3$ & $104-138$ & $10 Y R 4 / 3$ & $\mathrm{~m} 2 \mathrm{sbk}$ & h, vs, vp & - & Pressure faces \\
\hline & $6 \mathrm{Bw} 4$ & $138-170$ & 10YR $3 / 3$ & $\mathrm{~m} 2 \mathrm{sbk}$ & $h, v s, v p$ & - & Pressure faces \\
\hline
\end{tabular}


Table 2. Physical and chemical properties of the soils of Madahalli micro-watershed

\begin{tabular}{|c|c|c|c|c|c|c|c|c|c|c|c|c|c|}
\hline \multirow[t]{2}{*}{$\begin{array}{l}\text { Hori- } \\
\text { zon }\end{array}$} & \multirow[t]{2}{*}{$\begin{array}{l}\text { Depth } \\
\text { cm }\end{array}$} & \multicolumn{3}{|c|}{$\begin{array}{l}\text { Particle size distribution } \\
(\% \text { of }<2 \mathrm{~mm})\end{array}$} & \multirow[t]{2}{*}{$\begin{array}{l}\text { Organic } \\
\text { carbon } \\
\left(\mathrm{gkg}^{-1}\right)\end{array}$} & \multirow[t]{2}{*}{ pH } & \multirow[t]{2}{*}{$\begin{array}{c}\mathrm{EC} \\
\left(\mathrm{dSm}^{-1}\right)\end{array}$} & \multicolumn{4}{|c|}{$\begin{array}{l}\text { Exchangeable bases } \\
\left(\mathrm{cmol}\left(\mathrm{p}^{+}\right) \mathrm{kg}^{-1}\right)\end{array}$} & \multirow[t]{2}{*}{ CEC } & \multirow[t]{2}{*}{$\begin{array}{c}\text { Base } \\
\text { saturati } \\
\text { on (\%) }\end{array}$} \\
\hline & & $\begin{array}{c}\text { Sand } \\
(2.0-0.05 \\
\text { mm) }\end{array}$ & $\begin{array}{c}\text { Silt } \\
(0.05- \\
0.002 \mathrm{~mm})\end{array}$ & $\begin{array}{c}\text { Clay } \\
(<0.00 \\
2 \mathrm{~mm})\end{array}$ & & & & \multirow[t]{2}{*}{$\mathrm{Ca}$} & \multirow[t]{2}{*}{ Mg } & \multirow[t]{2}{*}{$\mathbf{N a}$} & $\mathbf{K}$ & & \\
\hline \multicolumn{11}{|c|}{ Pedon 1} & & & \\
\hline Ap & $0-18$ & 82.5 & 4.5 & 13.4 & 11.6 & 6.14 & 0.45 & 4.36 & 0.61 & 0.45 & 0.59 & 4.1 & 100 \\
\hline $\mathrm{Bw}$ & $18-29$ & 80.5 & 5.8 & 13.5 & 10.6 & 6.21 & 0.27 & 2.72 & 0.64 & 0.27 & 0.65 & 4.7 & 91 \\
\hline Bt1 & $29-48$ & 51.5 & 12.0 & 36.3 & 8.8 & 5.88 & 0.46 & 5.35 & 0.97 & 0.22 & 0.55 & 12.3 & 58 \\
\hline $\mathrm{Bt} 2$ & $48-69$ & 55.0 & 19.8 & 35.2 & 8.1 & 6.41 & 0.49 & 4.11 & 1.0 & 0.13 & 0.51 & 12.7 & 45 \\
\hline \multicolumn{14}{|c|}{ Pedon 2} \\
\hline Ap & $0-22$ & 58.8 & 11.9 & 33.3 & 12.3 & 7.57 & 0.97 & 10.05 & 1.34 & 0.65 & 0.49 & 10.3 & 100 \\
\hline Bt1 & $22-46$ & 50.1 & 11.3 & 38.6 & 5.3 & 7.67 & 0.47 & 2.88 & 1.02 & 0.26 & 0.73 & 12.8 & 38 \\
\hline $\mathrm{Bt} 2$ & $46-74$ & 57.0 & 13.0 & 32.0 & 7.4 & 7.64 & 0.37 & 3.4 & 1.07 & 0.15 & 0.84 & 14.5 & 38 \\
\hline $\mathrm{Bt} 3$ & $74-96$ & 50.2 & 14.80 & 35.0 & 4.2 & 7.44 & 0.34 & 3.96 & 1.11 & 0.19 & 0.86 & 19.1 & 32 \\
\hline \multicolumn{14}{|c|}{ Pedon 3} \\
\hline Ap & $0-13$ & 83.2 & 2.7 & 15.1 & 9.5 & 6.28 & 0.38 & 3.61 & 0.99 & 0.35 & 0.63 & 6.7 & 83 \\
\hline $\mathrm{Bt1}$ & $13-41$ & 57.9 & 6.2 & 35.6 & 7.4 & 5.86 & 0.32 & 3.48 & 0.71 & 0.24 & 0.56 & 9.7 & 51 \\
\hline $\mathrm{Bt} 2$ & $41-83$ & 54.5 & 9.7 & 35.8 & 7.7 & 5.89 & 0.33 & 3.36 & 0.76 & 0.19 & 0.55 & 10.7 & 45 \\
\hline \multicolumn{14}{|c|}{ Pedon 4} \\
\hline Ap & $0-13$ & 65.0 & 13.9 & 20.1 & 6.3 & 5.26 & 0.95 & 4.71 & 0.41 & 0.29 & 0.36 & 6.2 & 93 \\
\hline Bt1 & $13-36$ & 62.5 & 6.2 & 31.5 & 5.3 & 5.75 & 1.29 & 4.9 & 0.83 & 0.28 & 0.55 & 12.9 & 51 \\
\hline $\mathrm{Bt} 2$ & $36-61$ & 49.8 & 9.8 & 41.4 & 4.6 & 6.19 & 0.90 & 4.67 & 1.14 & 0.36 & 0.97 & 19.9 & 36 \\
\hline $\mathrm{Bt} 3$ & $61-83$ & 52.8 & 11.7 & 35.5 & 4.2 & 6.24 & 0.71 & 5.1 & 0.82 & 0.31 & 0.73 & 18.2 & 38 \\
\hline $\mathrm{Bt} 4$ & $83-106$ & 76.5 & 2.9 & 21.6 & 4.8 & 6.78 & 0.79 & 2.95 & 0.7 & 0.15 & 0.63 & 7.4 & 60 \\
\hline \multicolumn{14}{|c|}{ Pedon 5} \\
\hline Ap & $0-20$ & 71.0 & 8.7 & 23.3 & 6.3 & 7.02 & 0.31 & 1.97 & 0.64 & 0.41 & 0.08 & 4.3 & 72 \\
\hline $\mathrm{Bw}$ & $20-38$ & 72.1 & 7.4 & 20.5 & 12.3 & 7.15 & 0.43 & 1.9 & 0.61 & 0.19 & 0.58 & 9.1 & 36 \\
\hline $\mathrm{Bt} 1$ & $38-69$ & 44.0 & 15.1 & 40.1 & 8.1 & 7.17 & 0.52 & 3.97 & 0.72 & 0.13 & 0.82 & 10.8 & 52 \\
\hline $\mathrm{Bt} 2$ & $69-98$ & 59.4 & 5.6 & 36.0 & 8.8 & 6.68 & 0.44 & 2.8 & 0.82 & 0.12 & 0.96 & 9.6 & 49 \\
\hline $\mathrm{Bt} 3$ & $98-134$ & 57.6 & 7.4 & 36.2 & 5.6 & 7.02 & 0.25 & 1.88 & 0.51 & 0.14 & 0.93 & 8.9 & 39 \\
\hline \multicolumn{14}{|c|}{ Pedon 6} \\
\hline Ap & $0-26$ & 74.1 & 7.3 & 20.6 & 7.0 & 7.96 & 0.52 & 6.19 & 1.35 & 0.24 & 0.72 & 8.5 & 100 \\
\hline $2 \mathrm{~A} 2$ & $26-51$ & 82.2 & 2.3 & 12.5 & 6.3 & 7.93 & 0.53 & 5.4 & 0.09 & 0.45 & 0.58 & 7.3 & 89.3 \\
\hline 3Bw1 & $51-72$ & 72.0 & 6.6 & 22.4 & 2.1 & 8.17 & 0.47 & 3.53 & 0.7 & 0.15 & 0.78 & 4.7 & 100 \\
\hline $4 \mathrm{Bw} 2$ & $72-104$ & 58.0 & 8.2 & 30.8 & 6.0 & 7.79 & 0.64 & 3.63 & 1.13 & 0.19 & 0.79 & 10.1 & 56.8 \\
\hline $5 \mathrm{Bw} 3$ & $104-138$ & 26.7 & 30.3 & 40.0 & 2.8 & 7.85 & 0.72 & 6.06 & 1.79 & 0.23 & 0.92 & 12.7 & 70.9 \\
\hline 6Bw4 & $138-170$ & 55.5 & 9.5 & 35.0 & 4.2 & 8.06 & 0.66 & 5.37 & 1.5 & 0.22 & 0.65 & 13.2 & 58.6 \\
\hline
\end{tabular}

Soilclassification

Based on the morphological characteristics, physical and chemical properties of the typifying pedons, all the upland soils are grouped under Alfisols and the lowland soils under Inceptisols (Fig. 2). Six soil series were identified and mapped with 30 mapping units (phases of soil series). Moderately deep, well drained red gravelly sandy loam soils (M1 and M4 series); occupy nearly 47 per cent of the watershed area (330 ha). Series M5, which is very deep dark red sandy clay loam soils, cover an area of 326 ha. Other soils cover less than 5 per cent of the area in the watershed. 


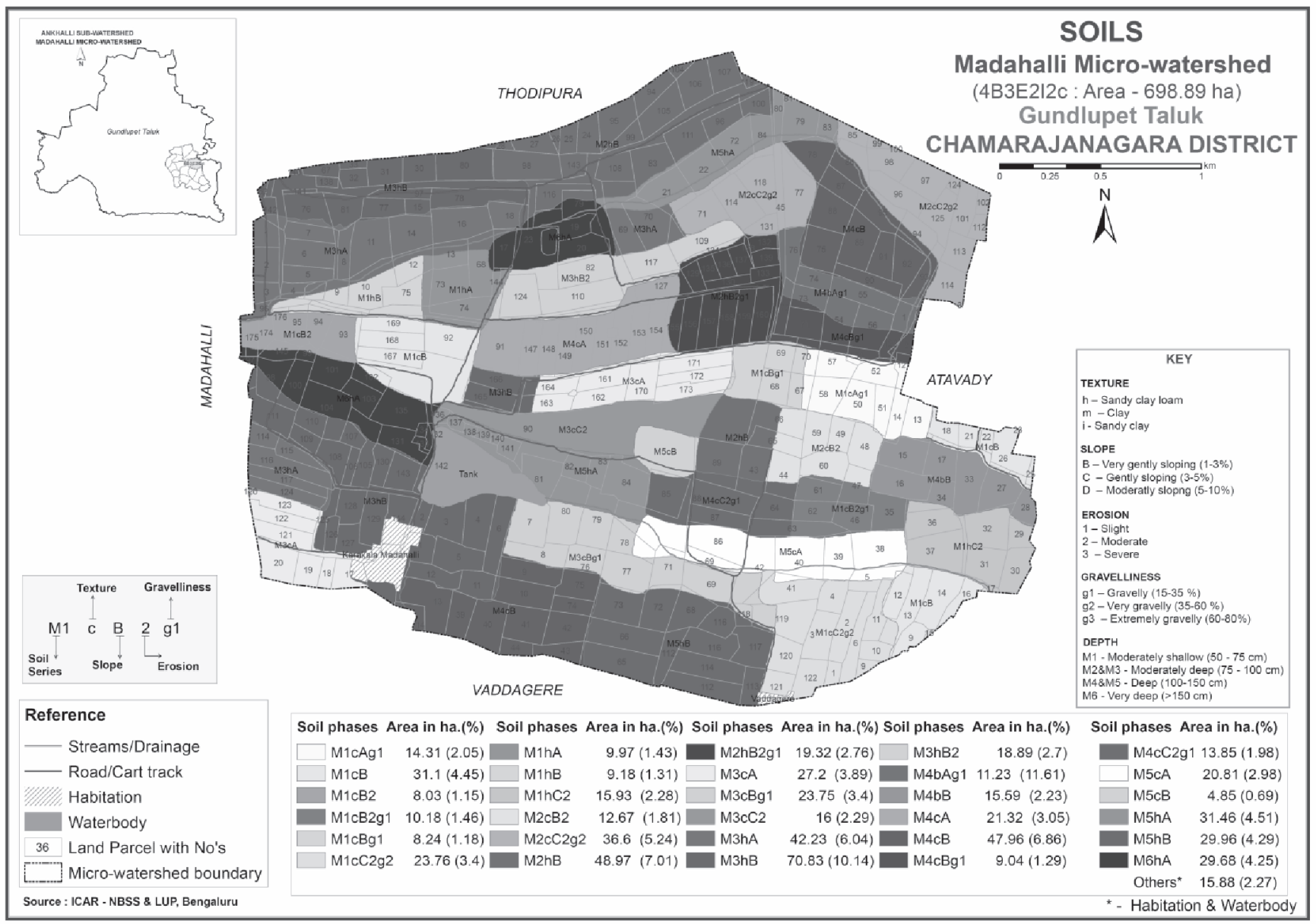

Fig.2. Soils of Madahalli microwatershed

\section{Description of soil series}

Series M1 (Madahalli-1)

The soils of Series M1 belonging to clayeyskeletal, mixed isohyperthermic Rhodic Paleustalfs are slightly deep, well drained with gravelly sandy loam texture. The clay content varied from 13.4 to 35.2 per cent in the sub-soil. The $\mathrm{pH}$ of the surface layer is 6.14 and it increased with depth. The EC of surface soil is $0.45 \mathrm{dS} \mathrm{m}^{-1}$. The organic carbon content of surface soil is $11.6 \mathrm{~g} \mathrm{~kg}^{-1}$ and it decreased with depth.

\section{Series M2 (Madahalli-2)}

Soil series M2 representing clayey-skeletal, mixed isohyperthermic Typic Rhodustalfs had relatively higher clay content (38.6\%) in sub-soil than the surface layer $(33.3 \%)$. The surface soil had $\mathrm{pH} 7.57$ but it decreased in sub soil. Electrical conductivity was higher in surface layer than sub-soil. Organic carbon content of surface soil is $12.3 \mathrm{~g} \mathrm{~kg}^{-1}$ and it decreased with depth.

\section{Series M3 (Madahalli-3)}

Clayey-skeletal, mixed isohyperthermic Rhodic Paleustalfs representing M3 series had higher clay accumulation in sub soil $(35.8 \%)$ than overlying horizon $(15.1 \%)$

The $\mathrm{pH}$ of the surface soil is 6.28 and in the sub soil it varies from 5.86 to 5.89 . EC is less and varies from 0.38 in the surface to $0.33 \mathrm{dS} \mathrm{m}^{-1}$ in the sub-soil. Organic carbon content of surface soil is $9.5 \mathrm{~g} \mathrm{~kg}^{-1}$ and it decreases with depth to $7.7 \mathrm{~g} \mathrm{~kg}^{-1}$.

\section{Series M4 (Madahalli-4)}

Soils were classified as clayey-skeletal, mixed isohyperthermic Typic Rhodustalfs. The clay content 
increases from the surface (20.1\%) to the sub-soil (35.5 per cent). The $\mathrm{pH}$ of the surface soil is 5.6 and it increases in the sub-soil to 6.78. Organic carbon content of surface soil is $6.3 \mathrm{~g} \mathrm{~kg}^{-1}$ and it decreases with depth to $4.8 \mathrm{~g} \mathrm{~kg}^{-1}$. Base saturation of soil ranges from 36 to 93 per cent.

\section{Series M5 (Madahalli-5)}

The clayey-skeletal, mixed isohyperthermic Typic Rhodustalfs have sandy loam to sandy clay loam texture. Clay content varies from 20.5 to 40.1 per cent. Soil $\mathrm{pH}$ of surface and sub-surface layers are 7.02. EC in surface soil layer is $0.31 \mathrm{dS} \mathrm{m}^{-1}$ whereas in sub-surface layer it varies from 0.9 to $0.18 \mathrm{dS} \mathrm{m}^{-1}$. Organic carbon content of surface soil is $6.3 \mathrm{~g} \mathrm{~kg}^{-1}$ and it increases with depth to $12.3 \mathrm{~g} \mathrm{~kg}^{-1}$. Base saturation of soil ranges from 36 to 72 per cent.

\section{Series M6 (Madahalli-6)}

In the soils of M6 series (Fine, mixed isohyperthermic Typic Haplustepts), clay content increases from the surface $(26.4 \%)$ to the sub-soil $(40.0 \%)$. The $\mathrm{pH}$ of soil increased in the sub-soil to 7.9 from 7.0 (surface soil). The Ap horizon had low EC than the sub-soils (5.2 to $0.66 \mathrm{dS} \mathrm{m}^{-1}$ ). Organic carbon content of surface soil is $7.0 \mathrm{~g} \mathrm{~kg}^{-1}$ and it decreased with depth to $2.1 \mathrm{~g} \mathrm{~kg}^{-1}$. Base saturation of soil ranged from 56.8 to 100 percent.

\section{References}

Black, C.A. (1965). Methods of Soil Analysis. Part 2, American Society of Agronomy Inc., Publisher, Madison, Wisconsin, USA, pp. 849-1348.

Meena, R.S., Natarajan, A., Thayalan, S., Hegde, R., Niranjana, K.V., Naidu, L.G.K., and Sarkar, D., (2014). Characterization and classification of lowland soils of Chikkarsinkere Hobli, Maddur taluk, Mandya district of Karnataka. Agropedology 24, 95-101.

Soil Survey Staff (2010). 'Keys to Soil Taxonomy', Eleventh Edition. (U.S.D.A.: Washington, D.C.).

Srinivasan, R., Natarajan, A., Anil Kumar K.S., and Kalaivanan (2013). Characterization of major cashew-growing soils of Dakshina Kannada district of Karnataka. Agropedology 23, 59-64.

Received: September, 2017 Accepted: February, 2018 